\title{
VISUOMENĖS ŽINIŲ IR NUOMONĖS APIE PROTARPINI BADAVIMĄ TYRIMAS
}

\author{
Kristina Žalnieraitė, Žymantė Jankauskienė, Erika Kubilienė \\ Vilniaus kolegijos Sveikatos priežiūros fakulteto Medicinos technologiju ir dietetikos katedra
}

Raktažodžiai: protarpinis badavimas, antsvoris, nutukimas, maitinimosi įpročiai.

\begin{abstract}
Santrauka
Šiuolaikinès visuomenès maitinimosi poreikius lemia greitejantis gyvenimo tempas, maisto produktų pasirinkimo gausa, maitinimosi metodų ir dietų ịvairovè. Naujų dietų populiarumui ir visuomenès nuomonès formavimui didelę įtaką daro socialinè aplinka ir masinè medija. Tinkamas visuomenès informavimas yra būtina sąlyga, siekiant išvengti klaidingai suprantamos ir (arba) interpretuojamos informacijos neigiamo poveikio asmens sveikatai. Tyrimo tikslas - iqvertinti visuomenès žinias ir nuomonę apie protarpinį badavimą. Tyrimo tikslui pasiekti išanalizuoti 200 respondentų atsakymai apie protarpinį badavimą (PB). Tyrimo rezultatai parode, kad 97 proc. respondentų PB renkasi noredami palaikyti optimalią kūno masę, pakeisti gyvenimo būdą ir pagerinti sveikatą. Dauguma respondentu ( 92 proc.) apie PB pirmą kartą išgirdo naudodamiesi socialiniais tinklais (Facebook, Instagram, Twitter). Tiriamieji (36 proc.) PB terminą dažniausiai tapatino su valgymo ir nevalgymo laikotarpių trukme. Dauguma nurodè atsisakantys pusryčių ir pietų bei pasirenkantys vėlyvą vakarienę. Tyrimo metu nustatyti PB principų pasirinkimo motyvai - metodo paprastumas, noras mažinti kūno masę, keisti gyvenimo būdą ar gerinti sveikatą. PB principų taikymas respondentams padejjo kontroliuoti suvartojamo maisto porcijų dydį, laikytis disciplinos ir kontroliuoti kūno masę.
\end{abstract}

\section{Ivadas}

Pasaulio sveikatos organizacijos (PSO) $2016 \mathrm{~m}$. duomenimis, daugiau nei 1,9 milijardo žmonių pasaulyje turejjo antsvorio, o per 650 milijonų buvo nutukę [1]. Didejjantis antsvorio ir nutukimo paplitimas (2 iš 3 suaugusiujų patiria šią problemą) skatina ieškoti naujų, efektyvių, šiuolaikinès visuomenès poreikius atitinkančių dietų, maitinimosi būdų, padedančių efektyviai mažinti kūno masę [2]. Kūno masès didèjimas neigiamai veikia žmogaus fizinę, emocinę sveikatą, didina riziką susirgti lètinėmis ligomis, įskaitant II tipo diabetą, širdies ir kraujagyslių, onkologines ligas [3].

Siekiant suvaldyti nutukimo ir antsvorio problemas, kuriami gydymo metodai, priemonės, skatinančios koreguoti gyvenimo būdą, maitinimąsi, fizinị aktyvumą, psichinę sveikatą [3]. Daugelio naujų dietų ar kitų svorio mažinimo metodų taikymas duoda minimalius, trumpalaikius rezultatus, kurių nepakanka nustatyti ir patvirtinti taikytų metodų klinikinị poveikị bei veiksmingumą [4].

Pasaulyje sparčiai populiarinamos ịvairios dietos mažinti kūno masę, kurias, neatsižvelgiant ị mokslinio pagrindimo trūkumą ar klaidingą interpretavimą, renkasi vis daugiau su antsvoriu arba nutukimu kovojančių žmonių [5]. Pastaruoju metu visuomeneje, masinèse medijose, mokslininkų bendruomeneje vis dažniau minimas protarpinis badavimas (PB) ir jo nauda žmogaus organizmui. Dažniausiai praktikuojamos PB formos yra periodinis ilgalaikis badavimas ir ribotas maitinimasis tam tikromis valandomis. Periodinis ilgalaikis badavimas - kai susilaikoma nuo valgymo 24 valandas vieną arba dvi dienas per savaitę, o kitomis dienomis mažinamas suvartojamų kalorijų kiekis [6]. Ribotas maitinimasis tam tikromis valandomis - kai pasirenkamas tam tikras laikas, kuriuo valgoma ir kuriuo susilaikoma nuo maisto. Populiariausias šio metodo variantas - kai 16 valandų susilaikoma nuo maisto vartojimo, o 8 valandas valgoma [6]. Didejjant PB populiarumui ir informacijos sklaidai apie PB naudą žmogaus organizmui, labai svarbu, kad visuomenę pasiekianti informacija būtų teisingai suprantama, interpretuojama ir taikoma praktikoje.

Tyrimo tikslas - įvertinti visuomenès žinias ir nuomonę apie protarpinị badavimą.

\section{Tyrimo medžiaga ir metodai}

Tyrimo duomenys rinkti $2020 \mathrm{~m}$. sausio $1 \mathrm{~d}$. - kovo 31 d. laikotarpiu, išsiunčiant apklausos anketą elektroniniu būdu 200 respondentų, besidominčių PB principais ir ịsigijusių 
mobiliają aplikaciją, skirtą taikyti PB. Visi apklaustieji domisi ir (arba) propaguoja protarpinį badavimą. Respondentų amžius nuo 18 iki 60 metų ir daugiau.

Tyrimui naudotas klausimynas, kurị sudare 21 klausimas: 2 klausimai skirti demografinei respondentų charakteristikai apibūdinti, 12 - išsiaiškinti bendrąsias žinias, susijusias su PB ir 8 klausimai apie maitinimosi ir gyvensenos ypatumus.

Gautieji duomenys ir tyrimo rezultatai apdoroti SPSS standartinio paketo programine iqranga. Skirtumas tarp kintamųju, pasirinkus reikšmingumo lygmenį $\alpha=0,05$, laikomas statistiškai reikšmingu ir patikimu, kai apskaičiuotoji $\mathrm{p}$ reikšmė yra ne didesnè nei $0,05(\mathrm{p} \leq 0,05)$. Kintamųų pasiskirstymo dažnis išreikštas procentais.

\section{Tyrimo rezultatai}

Gauta 200 užpildytų apklausos apie PB anketų. Daugiau nei du trečdalius respondentų ( 73,5 proc.) sudare moterys, trečdali (26,5 proc.) - vyrai. Skaitlingiausios amžiaus grupès

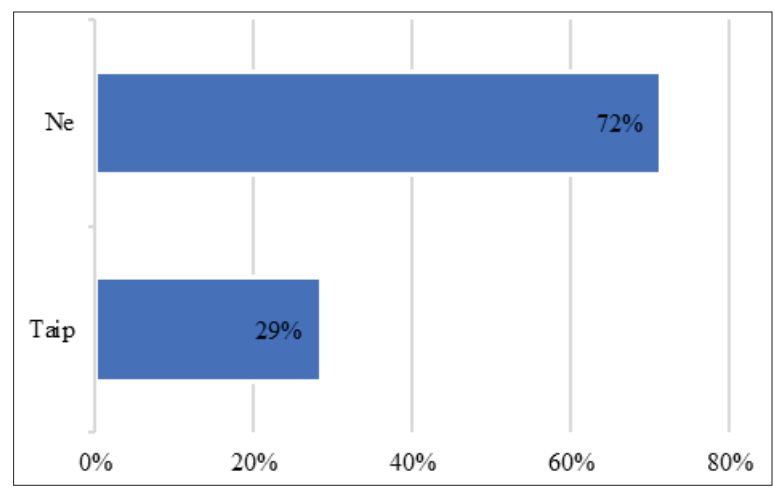

1 pav. Protarpinio badavimo principų taikymo dažnis, proc.

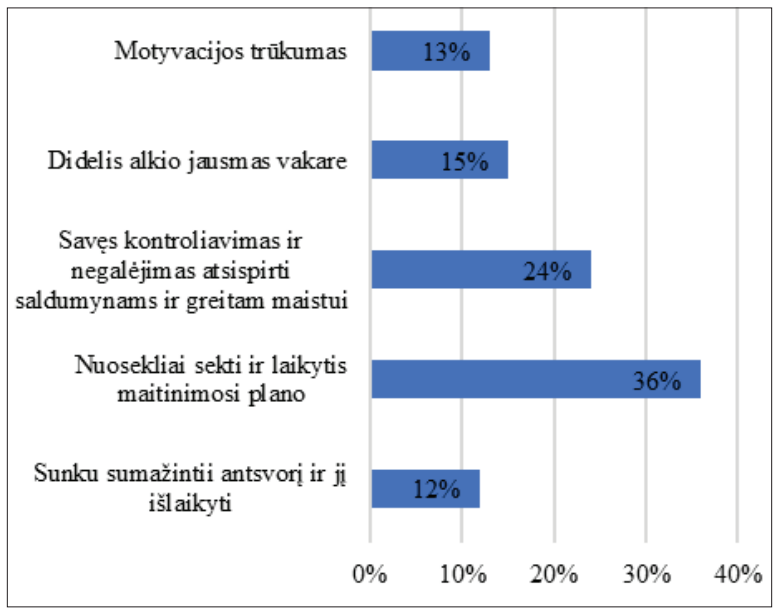

2 pav. Patirti kūno masès mažinimo sunkumai ir jų dažnis, sunkumai, norint sumažinti kūno masę, proc. buvo 60 metų ir vyresni (30 proc.) bei $50-59$ metų ( 29 proc.) respondentai.

Atlikus tyrimą nustatyta, kad trečdalis respondentų (29 proc.) jau anksčiau bandè taikyti PB principus praktikoje (35 proc. vyrų ir 25 proc. moteru) (1 pav.).

Siekiant įvertinti respondentų bendrąsias žinias apie PB ir priežastis, lèmusias šio maitinimosi metodo pasirinkimą, i apklausos anketą buvo įtraukti klausimai apie respondentų motyvaciją mažinti kūno masę ir dèl to patirtus sunkumus.

Daugiau nei trečdalis apklaustujų (36 proc.) nurodè, kad sunkiausia nuosekliai laikytis sudaryto maitinimosi plano ( 2 pav.). Ketvirtadalis respondentų ( 24 proc.) nurodè savikontrolès stoką ir negalejjimą atsispirti saldumynams bei greitmaisčiui (27 proc. vyrų ir 22 proc. moteru). Nustatytas statistiškai reikšmingas skirtumas $(p=0,035)$ tarp ịvairaus

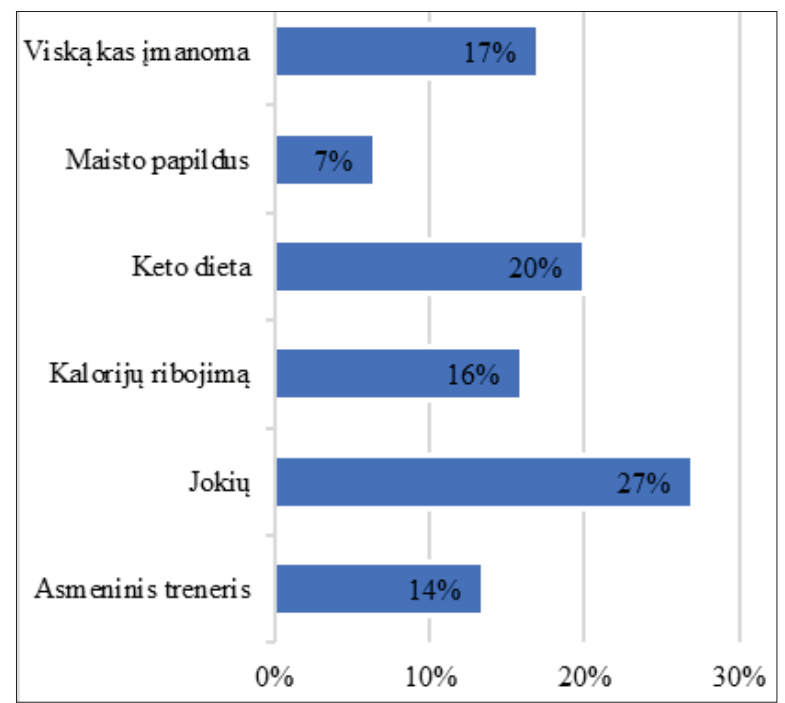

3 pav. Bandyti produktai ar programos, siekiant sumažinti kūno masę, proc.

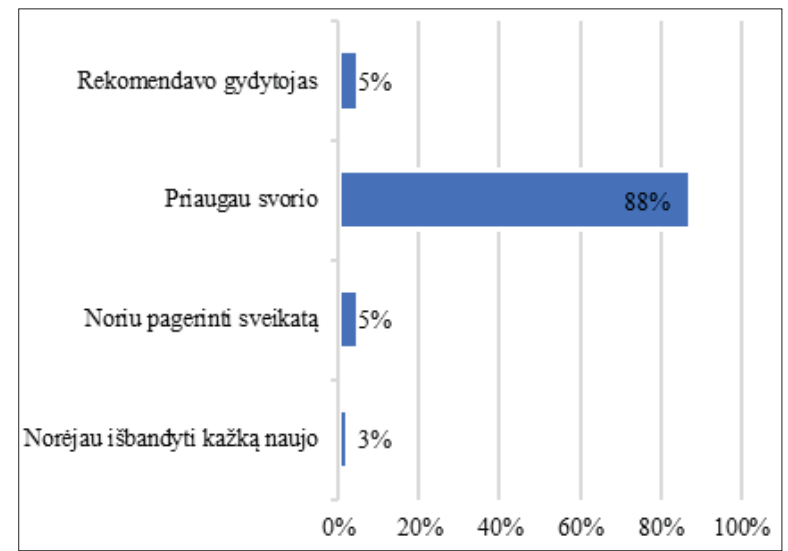

4 pav. Priežastys, lėmusios dietos ar naujo maitinimosi būdo paieškas, proc. 
amžiaus grupių respondentų patirtų kūno masès mažinimo sunkumų.

Kiek mažiau nei trečdalis respondentų ( 27 proc.) nebandè jokių produktų ar programų mažinti nepageidaujamą kūno masę. Ketogeninę (keto) dietą išbande penktadalis respondentų (20 proc.): 23 proc. vyru ir 19 proc. moteru (3 pav.). Nustatytas statistiškai reikšmingas skirtumas tarp vyrų ir moterų $(\mathrm{p}=0,018)$ bei tarp skirtingo amžiaus grupių respondentu ( $\mathrm{p}=0,024)$, pasirenkant ir išbandant lieknejimui skirtus produktus ar programas. Statistiškai reikšmingai daugiau ịvairių lieknèjimui skirtų produktų (programų) buvo išbandžiusios $21-29 \mathrm{~m}$. (87 proc.) ir 50-59 m. (73 proc.) moterys bei $40-49 \mathrm{~m}$. (92 proc.) ir $60>$ metu ( 89 proc.) vyrai.

Dažniausia naujos dietos ar maitinimosi būdo paieškos priežastis - padidejjusi kūno masè (88 proc.). Gydytojo rekomendaciją ar norą pagerinti sveikatą nurodè po 5 proc. tiriamujų (4 pav.).

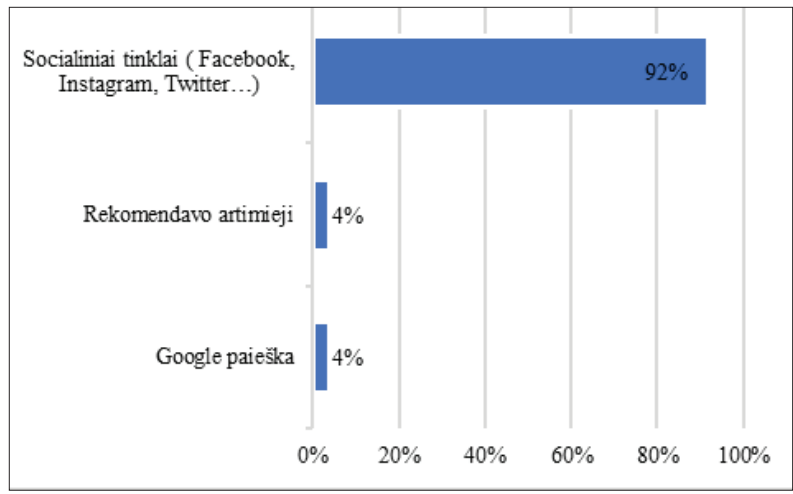

5 pav. Informacijos apie PB šaltiniai, proc.

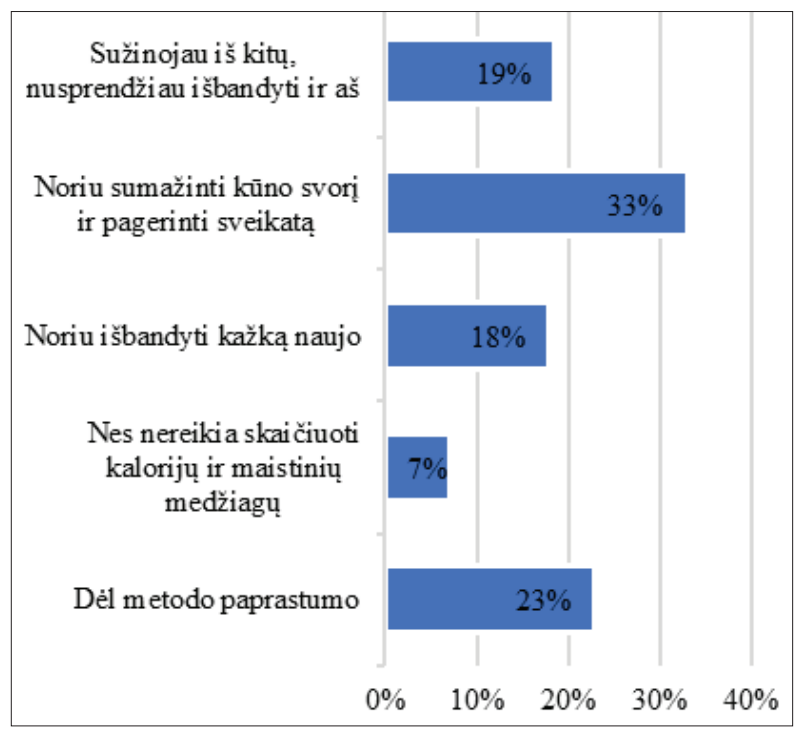

6 pav. Lūkesčiai, lėmę pasirinkimą taikyti PB principus, proc.
Didžioji dauguma respondentų (92 proc.) apie PB pirmą kartą išgirdo lankydamiesi socialiniuose tinkluose Facebook, Instagram, Twitter (5 pav.).

Pagrindiniai lūkesčiai, dèl kurių respondentai ketino taikyti PB principus - noras sumažinti kūno masę ir pagerinti sveikatą (33 proc.) bei metodo paprastumas ( 23 proc.) (6 pav.). Nustaty-

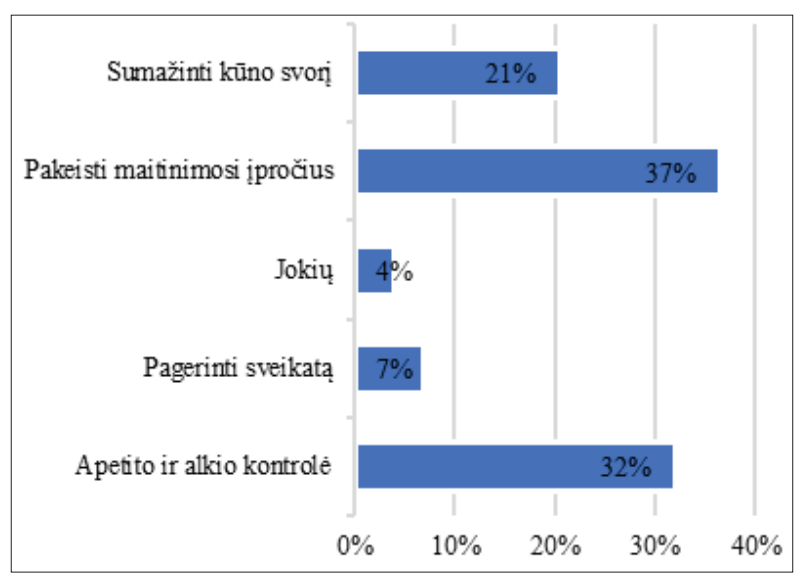

7 pav. Gyvensenos ar sveikatos problemos, siekiamos išspręsti taikant $\mathrm{PB}$ principus, proc.

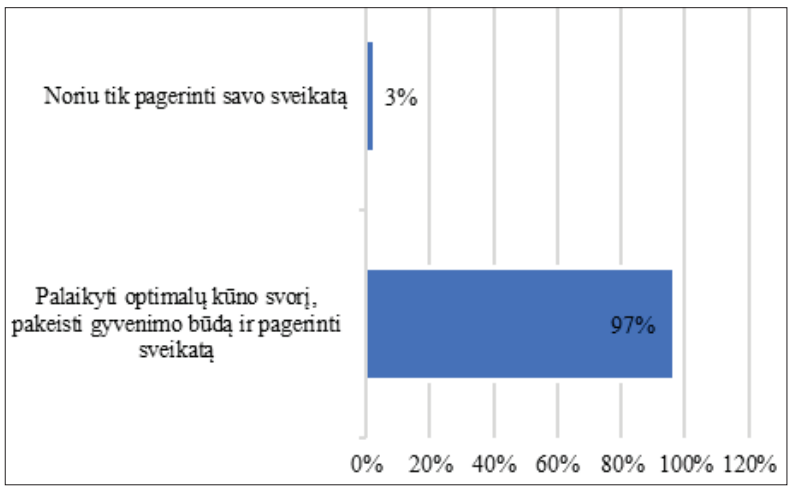

8 pav. PB pasirinkimo motyvai, proc.

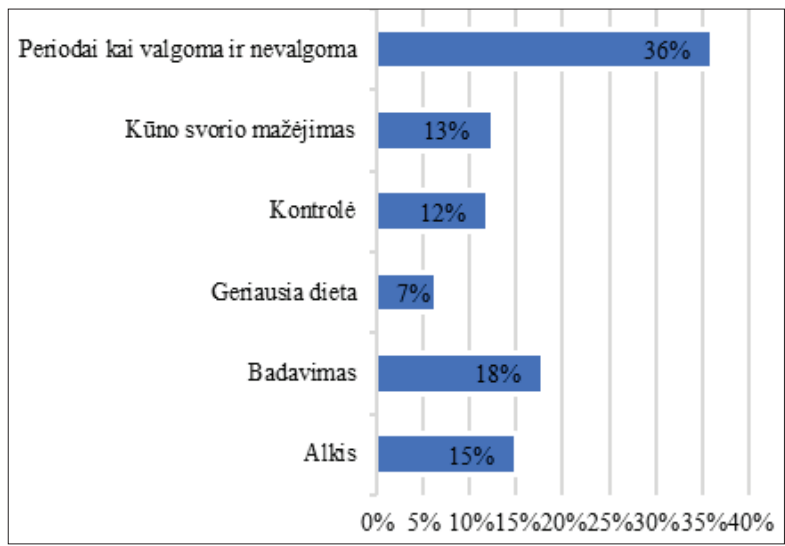

9 pav. PB termino asociacijos ir jų dažnis, proc. 
tas statistiškai reikšmingas skirtumas $(\mathrm{p}=0,003)$ tarp skirtingo amžiaus grupių respondentų lūkesčių taikyti PB principus.

Nusprendę taikyti PB principus, respondentai dažniausiai

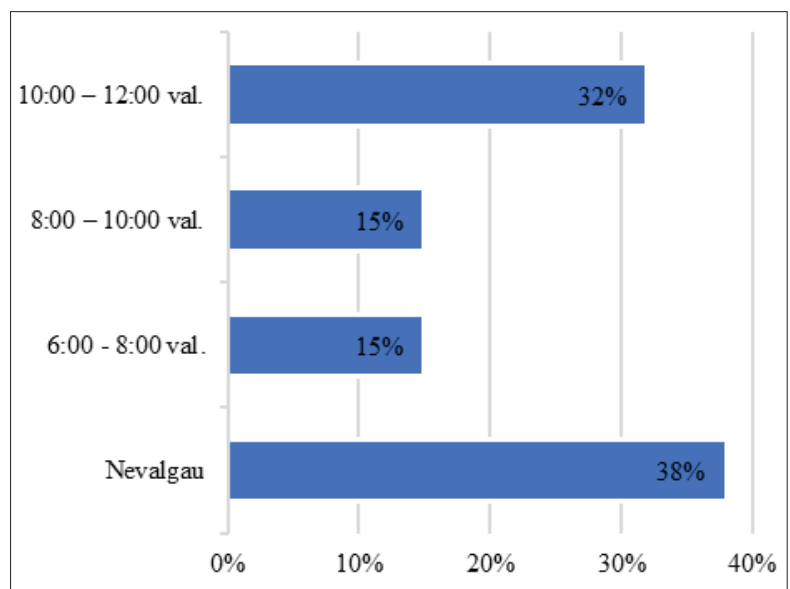

10 pav. Gyvenimo būdas iki susidomèjimo $P B$, proc.

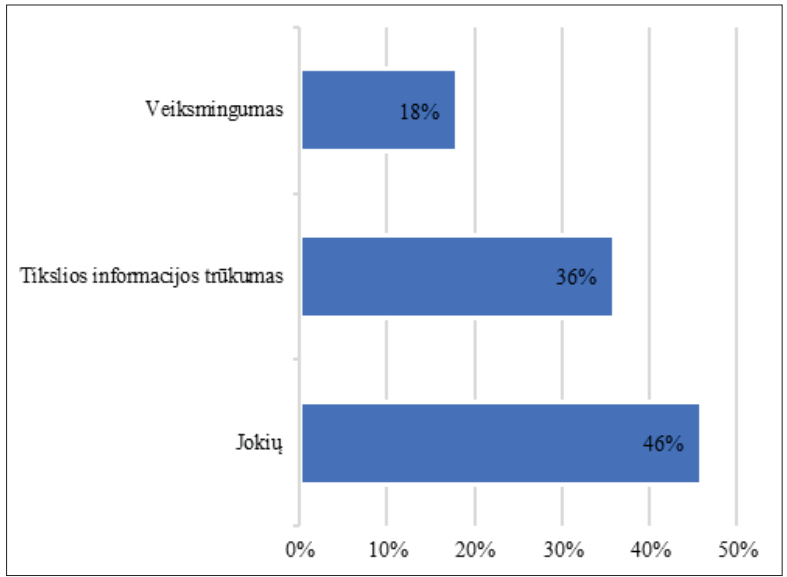

11 pav. Abejonès dèl PB principų taikymo, proc.

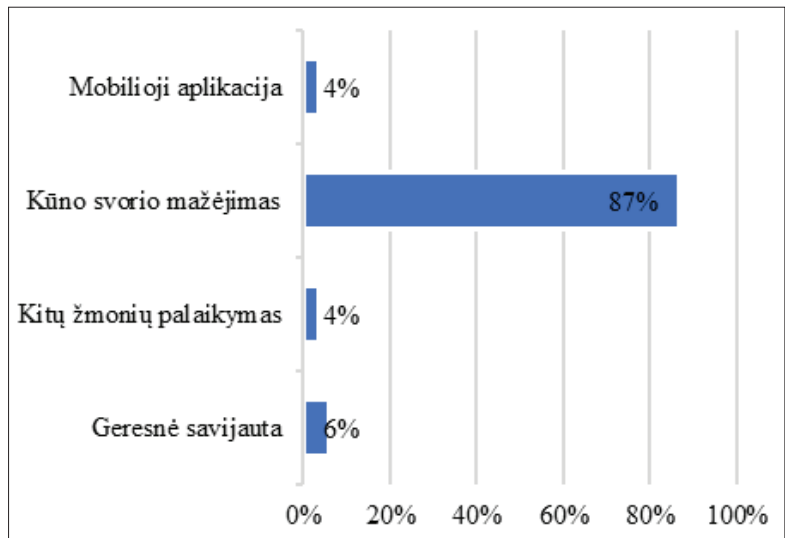

12 pav. Susidomèjimo PB ir jo taikymo ne ilgiau kaip mènesi motyvų dažnis, proc. nori pakeisti savo maitinimosi ịpročius (37 proc.), kontroliuoti apetitą bei alkị (32 proc.) (7 pav.).

Domėtis PB ar taikyti šio metodo principus, didžiają daugumą respondentų (97 proc.) labiausiai motyvavo noras palaikyti optimalią kūno masę, keisti gyvenseną ir pagerinti sveikatą (8 pav.).

PB terminas respondentams dažniausiai asocijuojasi su valgymo ir nevalgymo laikotarpiais (36 proc.), badavimu (18 proc.) ir alkiu (15 proc.) (9 pav.). Mokslinèje literatūroje pateikiama informacija apie pagrindinius protarpinio badavimo principus koreliuoja su respondentų atsakymais.

Trečdalio respondentų (32 proc.) apsisprendimą domètis ir taikyti PB principus lèmé disciplinos ir motyvacijos trūkumas, ketvirtadalis (24 proc.) nurodè, kad yra išmėginę visas imanomas dietas (10 pav.). Nustatytas statistiškai reikšmingas koreliacinis ryšys $(p=0,018)$ tarp respondentų gyvenimo būdo

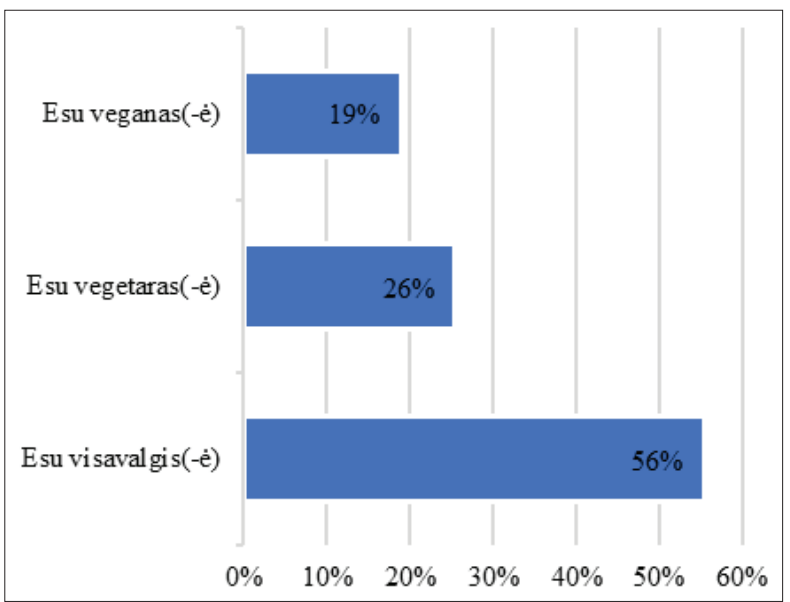

13 pav. Maitinimosi būdas, proc.

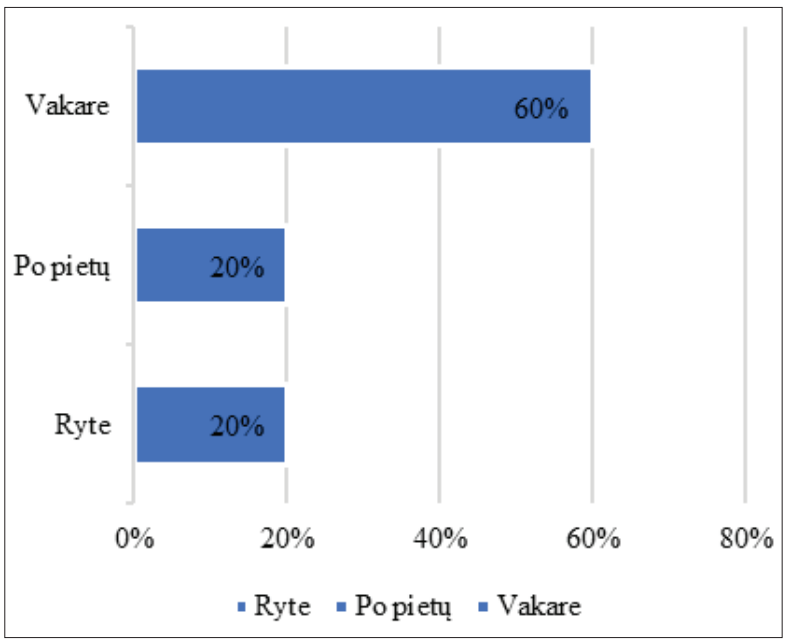

14 pav. Alkio pojūtis dienos metu, proc. 
prieš pradedant domètis $\mathrm{PB}$ ir jų apsisprendimo taikyti $\mathrm{PB}$. Labiausiai motyvuoti buvo tie respondentai, kurie anksčiau nevalde alkio (63 proc.) ir persivalgydavo vakarais ( 47 proc.).

Pusè respondentu (46 proc.), ketindami taikyti PB, neabejojo šio metodo patikimumu, vis dèlto trečdalis (36 proc.)

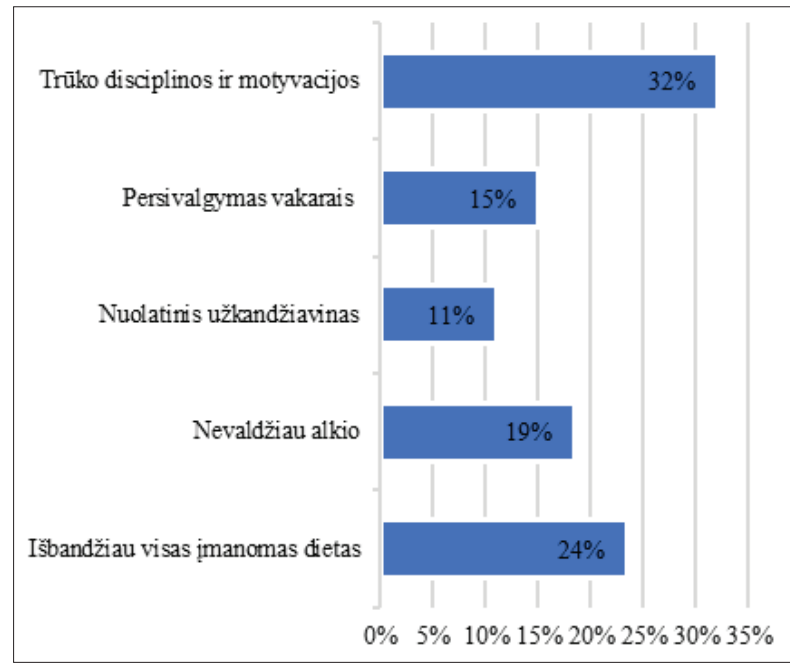

15 pav. Pusryčių valgymo laikas, proc.

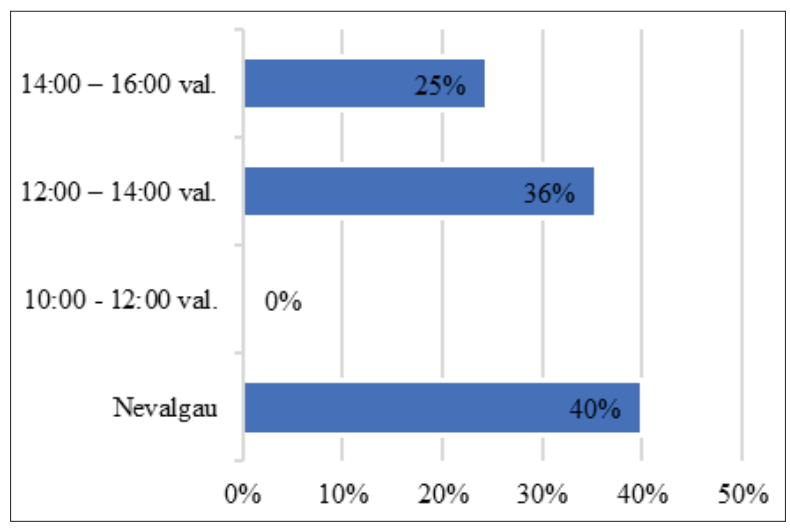

16 pav. Pietų valgymo laikas, proc.

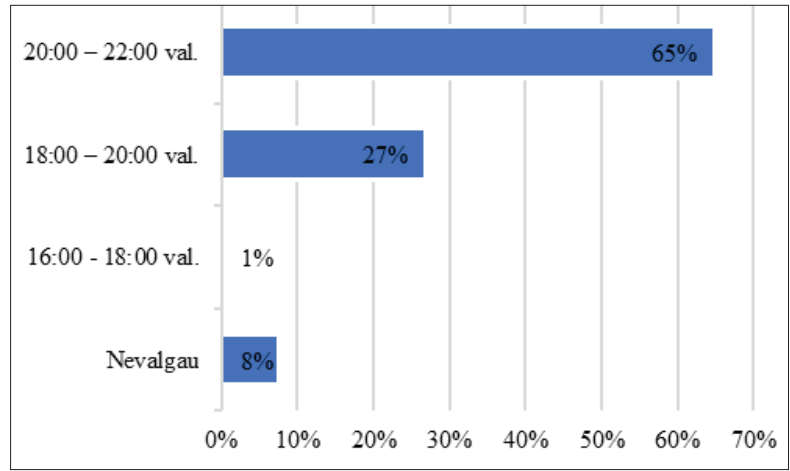

17 pav. Vakarienès valgymo laikas, proc. nurodè, kad abejonių sukėlè tikslios informacijos trūkumas (11 pav.).

Didžioji dauguma respondentų (87 proc.) nurodè, kad domètis ir taikyti PB principus ilgiau nei vieną mènesį juos labiausiai motyvuotų mažejjanti kūno masè (12 pav.).

Respondentų maitinimosi ir gyvensenos vertinimui buvo pateikti klausimai apie maitinimosi ịpročius, fizinį aktyvumą, kasdienę rutiną.

Daugiau nei pusė respondentų (56 proc.) nurodè esantys visavalgiai (44 proc. vyrų ir 58 proc. moteru), ketvirtadalis (26 proc.) - vegetarai (42 proc. vyru ir 23 proc. moteru), penktadalis (19 proc.) - veganai (14 proc. vyrų ir 19 proc. moterų) (13 pav.). Nustatytas statistiškai reikšmingas skirtumas $(p=0,024)$ tarp vyrų ir moterų pasirinkto maitinimosi būdo ir statistiškai reikšmingas koreliacinis ryšys $(p=0,029)$ tarp maitinimosi būdo ir apsisprendimo pradèti PB. Visavalgiai statistiškai reikšmingai dažniau renkasi $\mathrm{PB}$, norèdami sumažinti kūno masę ir gerinti sveikatą (41 proc.), o

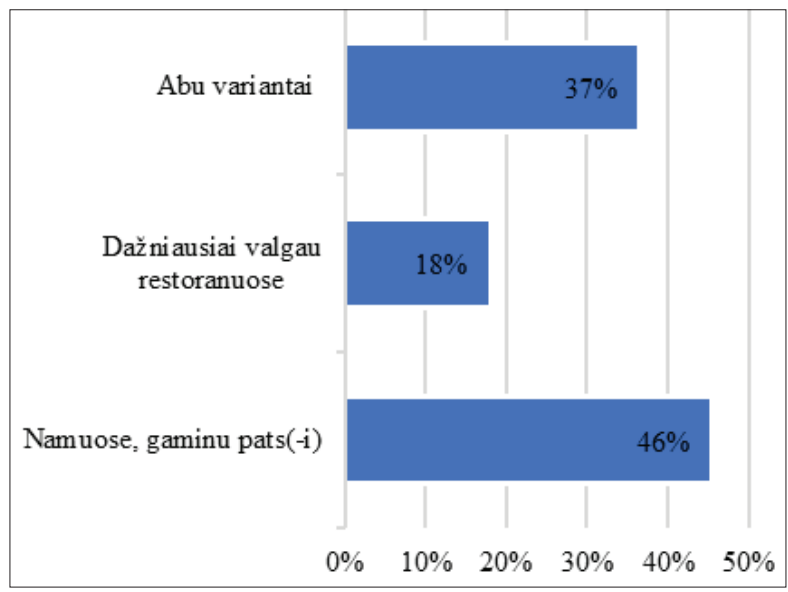

18 pav. Maitinimosi vieta, proc.

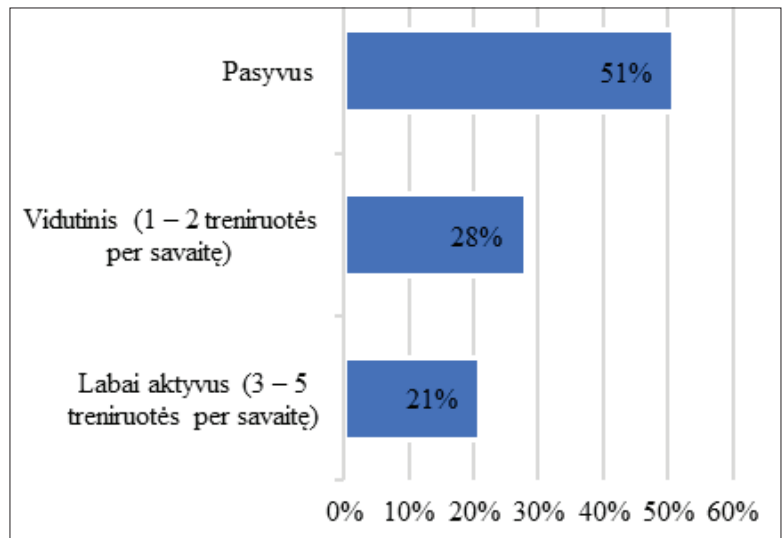

19 pav. Fizinis aktyvumas, proc. 
vegetarai ir veganai - dèl metodo paprastumo (24 proc. ir 34 proc. atitinkamai).

Daugiau nei pusè respondentu (60 proc.) nurodé, kad didžiausias alkio pojūtis aplanko vakarais. Ryte ir po pietų alkị dažniausiai jaučia po penktadali ( 20 proc.) respondentų (14 pav.).

Didesnè dalis respondentų (38 proc.) nurodè, kad pusryčių nevalgo, trečdalis (32 proc.) atsakè valgantys nuo 10:00 iki 12:00 valandos. Nors pusryčiu dažniau atsisako moterys (43 proc.) nei vyrai (29 proc.), statistiškai reikšmingo skirtumo $(\mathrm{p}<0,05)$ tarp lyčiu nebuvo nustatyta (15 pav.). Palyginus respondentų atsakymus apie pusryčių valgymo laiką su tinkamo maitinimosi principais, matyti, kad pusryčių atsisakymas neatitinka tinkamo maitinimosi principų, nes pusryčiai yra vienas iš trijų pagrindinių patiekalų sveiko žmogaus dietoje. PB principai taip pat neskatina atsisakyti pusryčių, o rekomenduotina atsisakyti vieno iš valgymų dienoje, siekiant pasiekti pasirinkto nevalgymo laiką. Remiantis PB ir cirkadinių ritmų (CR) teorijomis, analizuojančiomis žmogaus organizmo biologinius ritmus ir medžiagų apykaitos, fiziologinių procesų priklausomybę nuo paros laiko, žmogaus organizmas ryte geriausiai įsisavina maistines medžiagas, medžiagų apykaitos procesai efektyvesni, todèl siekiant palaikyti optimalią medžiagų apykaitą, bendrają sveikatą, palankiau atsisakyti vakarienès, nei pusryčių.

Kone pusė respondentų (40 proc.) nurodė nevalgantys pietu, 36 proc. tiriamujų pietus valgo 12:00-14:00 valandą. Ketvirtadalis respondentų ( 25 proc.) nurode pietus valgantys 14:00-16:00 valandą. Nustatyta, kad moterys statistiškai reikšmingai dažniau (47 proc.) nei vyrai (19 proc.) atsisako pietų ( $\mathrm{p}=0,009)$ (16 pav.). Palyginus respondentų pietų valgymo laiką su tinkamo maitinimosi principais, matyti, kad pietų atsisakymas yra netinkamas sprendimas, nes pietūs yra vienas iš trijų pagrindinių valgymų sveiko žmogaus dietoje. Vertinant PB ir CR teorijas, atsižvelgiant ị medžiagu apykaitos procesus pietu paros laiku, nerekomenduojama atsisakyti pietų, siekiant palaikyti optimalius medžiagų apykaitos procesus ir bendrają sveikatą.

Daugiau nei pusė respondentų (65 proc.) nurodė vakarienę valgantys 20:00-22:00 val., beveik trečdalis (27 proc.) 18:00-20:00 val. (17 pav.). Vakarienès atsisako po 6 proc. moterų ir vyrų, statistiškai reikšmingo skirtumo tarp lyčių nenustatyta. Palyginę vakarienès valgymo laiką su tinkamo maitinimosi principais ir PB bei CR teorijomis, gauname, kad respondentai klaidingai renkasi vakarienès laiką, nes pagal tinkamo maitinimosi principus, vakarienè turètų būti valgoma ne vèliau kaip likus 3 valandoms iki miego, o, ivvertinus organizmo CR - ne vèliau kaip 19 valandą.

Kone pusè respondentų (46 proc.) maistą gaminasi ir valgo namuose, o daugiau nei trečdalis (37 proc.) nurodè, kad maitinasi tiek namuose, tiek ir restoranuose (18 pav.).

Atlikus tyrimą nustatyta, kad pusė respondentų (51 proc.) nèra fiziškai aktyvūs (46 proc. vyrų ir 53 proc. moterų), beveik trečdalis (28 proc.) - vidutinio fizinio aktyvumo (37 proc. vyrų ir 25 proc. moterų). Dažniausiai pasyvų gyvenimo būdą nurodè 40-49, 50-59 ir 60> amžiaus grupių respondentai (atitinkamai 63 proc., 49 proc. ir 58 proc.grupių), tačiau statistiškai reikšmingo fizinio aktyvumo skirtumo $(\mathrm{p}<0,05)$ nebuvo nustatyta nei tarp skirtingo amžiaus grupių respondentų, nei tarp vyrų ir moterų (19 pav.).

\section{Rezultatų aptarimas}

Lietuvoje, kaip ir visame pasaulyje, antsvorio ir nutukimo problema didejja. Ištyrus visuomenès žinias ir nuomonę apie protarpini badavimą, nustatytas tik dalinis atitikimas moksliniuose šaltiniuose pateikiamai informacijai. Moksliniuose straipsniuose akcentuojama, kad pats populiariausias ir efektyviausias PB metodas, susilaikymas nuo maisto vartojimo tam tikrą valandų skaičių per dieną. PB metodas vertinamas kaip vienas iš efektyviausių, siekiant ilgalaikio kūno masès mažinimo rezultato [7]. Atlikto tyrimo rezultatai parodé, kad taikydami PB principus, respondentai siekia kontroliuoti porcijų dydị, pagerinti alkio kontrolę ir discipliną, tačiau pasirenka sveikos mitybos principų neatitinkantị maitinimosi režimą, dienos maisto davinio paskirstymą tarp pagrindinių valgymų. Dirbant su pacientais (klientais) individualiai, ar pasitelkus žiniasklaidos ir kitas priemones, tokias kaip socialiniai tinklai, populiarūs tinklaraščiai, elektroniniai dienraščiai, populiarūs žurnalai, laikraščiai, svarbu skleisti tinkamas žinias ir formuoti mokslo ịrodymais pagrịstą visuomenès nuomonę apie PB ir jo principus, kurie turi derèti su sveikos mitybos principais, akcentuoti galimą žalą organizmui, jei bus netinkamai pasirenkami ir taikomi PB metodai.

\section{Išvados}

1. Literatūros šaltiniuose nurodoma, kad PB principų taikymas padeda nutukusiems ar antsvorio turintiems asmenims sumažinti kūno masę, nustatytas teigiamas poveikis daugumai fiziologinių funkcijų, tačiau, norint patvirtinti teigiamą ilgalaikị PB poveikị žmogaus organizmui ir fiziologinèms funkcijoms, reikalingi išsamesni tyrimai.

2. Tyrimo rezultatai parodè, kad dauguma respondentų informacijos apie PB ieškojo socialinèse medijose ir daugiau nei pusė jų neabejojo PB principu patikimumu, vis dèlto daugiau nei trečdalis respondentų norejo išsamesnès informacijos.

3. Pagrindinis respondentų PB principų pasirinkimo motyvas - kūno masès kontrolè, pasitelkiant, jų nuomone, „paprastą“ metodą: valgymo ir nevalgymo laikotarpius su tam tikrais laiko intervalais. 
4. Respondentai, ketindami taikyti PB principus, siekia kontroliuoti porcijų dydį, pagerinti alkio kontrolę, sveikatą, discipliną, tačiau daugiau nei pusė tiriamųjų ignoruoja tinkamo maitinimosi principus ir cirkadinius organizmo ritmus, pasirinkdami netinkamą maitinimosi režimą, dienos maisto davinio paskirstymą tarp pagrindinių valgymų ir fizinį pasyvumą.

\section{Literatūra}

1. Obesity and overweight, WHO. https://www.who.int/newsroom/fact-sheets/detail/obesity-and-overweight

2. Flegal KM, Kruszon-Moran D, Carroll MD, Fryar CD, Ogden CL. (2016). Trends in obesity among adults in the United States, 2005 to 2014. JAMA 2016;315(21):2284-91.

https://doi.org/10.1001/jama.2016.6458

3. Hoddy KK, Kroeger CM, Trepanowski JF, Barnosky AR, Bhutani S, Varady KA. Safety of alternate day fasting and effect on disordered eating behaviors. Nutr J 2015;14(1):1.

https://doi.org/10.1186/s12937-015-0029-9

4. Laddu D, Dow C, Hingle M, Thomson C, Going S. A review of evidence-based strategies to treat obesity in adults. Nutr Clin Pract 2011;26(5):512-25.

https://doi.org/10.1177/0884533611418335

5. Ganesan K, Habboush Y, Sultan S. Intermittent fasting: the choice for a healthier lifestyle. Cureus 2018;10(7):e2947. https://doi.org/10.7759/cureus.2947

6. St-Onge MP, Ard J, Baskin ML, Chiuve SE, Johnson HM, Kris-Etherton P, Varady K. Meal timing and frequency: implications for cardiovascular disease prevention: a scientific statement from the American Heart Association. Circulation 2017;135(9):e96-e121.

https://doi.org/10.1161/CIR.0000000000000476

7. Patterson R, Laughlin GA, Sears D, LaCroix AZ, Marinac BA, Gallo LC, Hartman SJ, Natarajan L, Senger SM, Martínez ME, Villaseñor A. Intermittent fasting and human metabolic health. J Acad Nutr Diet 2015;115(8):1203-1212.

https://doi.org/10.1016/j.jand.2015.02.018

\section{SURVEY OF PUBLIC KNOWLEDGE AND OPINION ON INTERMITTENT FASTING}

K. Žalnieraitė, Ž. Jankauskienė, E. Kubilienė habits. eywords: intermittent fasting, overweight, obesity, eating

\section{Summary}

In Lithuania, as well as around the world, the accelerating pace of life, the abundance of food choices encourages the emergence of new nutrition methods and diets. The popularity of new diets is strongly influenced by the social environment and the mass media, which forms public knowledge and opinion on new dietary approaches. It is essential to ensure that knowledge and information reach society correctly understood and interpreted. Misunderstood or misinterpreted information might lead to a negative impact on personal health.

The object of the research - public knowledge and opinion about intermittent fasting (IF).

Methodology of the research - in order to achieve the goal of the research, the research was carried out based on the questionnaire answers of 200 respondents about the IF. The analysis of the research data was performed by the mathematical statistical analysis program SPSS Statistics.

The results of the study showed that 97 percent respondents chose IF to maintain optimal body weight, change lifestyle and improve health. The vast majority, 92 percents of respondents, heard about IF for the first time using social networks (Facebook, Instagram, Twitter ...). Intermittent fasting for 36 percent of respondents is most often associated with periods of eating and fasting.

The literature indicates that the application of IF principles helps people who are overweight and obese to lose weight and has found positive effects on most physiological functions, but more human studies are needed to confirm the positive long-term effects of IF on the human body and physiological functions. given that most of the findings of the studies are based on the results of studies with laboratory animals.

The results of the study showed that the respondents choose the principles of IF because of the simplicity of the method in order to reduce unwanted body weight, change lifestyle and improve health. Application of IF principles to respondents helps to better control portion sizes, adhere to discipline, and reduce body weight.

The respondents" opinion and knowledge about IF and its principles only partially correspond to the information about IF provided by scientific sources. Applying the principles of IF, the nutrition of the respondents does not comply with the principles of proper nutrition.

Correspondence to: zalnieraite@gmail.com

Gauta 2020-07-07 